\title{
MONEY, SECURITY, AND THE RELATIONSHIPS OF TRUST: TOWARD AN INTEGRATED UNDERSTANDING OF GORBACHEV'S ROLE IN GERMAN REUNIFICATION
}

\author{
Sean Eedy \\ Carleton University
}

\begin{abstract}
Constructivist theory has been part of the historiography of the Cold War's end and the unification of Germany since the late 1990s. However, much of the literature on the subject of Gorbachev and German unity interprets events using security and economics as having dictated Soviet policy of the period. This paper discusses Materialist, Realist, and Constructivist theories and their necessary interaction to provide a more thorough analysis of Gorbachev's role in German unity. It argues not only that German Unification was the unforeseen byproduct of Gorbachev's policies meant to revitalize the Soviet economy, but also that German unity was not possible until Gorbachev's economic and security concerns for the USSR's future were allayed. These concerns were not addressed by traditional measures, but through the trust developed between Gorbachev, West German Chancellor Helmut Kohl, and the Federal Republic of Germany. Constructivist theory adds significant dimensions to the existing interpretations of Materialist and Realist theories in explaining how Gorbachev addressed Soviet concerns and policies of reform during the process of German unification where earlier confrontationist policies failed.
\end{abstract}




\section{Introduction}

Shortly after his election to General Secretary of the Central Committee of the Communist Party of the Soviet Union (CPSU), Mikhail Gorbachev instituted a policy of Perestroika (restructuring) in order to correct flaws in the Soviet economy caused by the Stalinist top-down, command economic structure and reverse the slow economic downturn prevalent through the 1970s and 1980s. When coupled with his policy of Glasnost (openness), Perestroika not only sought to rebuild the Soviet economy, but also to restructure the political institutions initially responsible for the contraction of the Soviet Union's gross national product (GNP). By instituting a more democratic means of governance, it was hoped that socialism could be brought "more in accord with man's interests and needs (Gorbachev 1989b, 19)." That is, to increase the Soviet standard of living, as opposed to the continuation of measuring success based solely on the numbers of material output present in the Stalinist model of the planned economy. Effectively, Gorbachev's policies sought a third-way that might navigate the economy between sovietstyle communism and western capitalism and grant socialism a degree of popular legitimacy without the total abandonment of Marxist-Leninist ideals (Gedmin 1992, 3). However, through closer cooperation with the West, in particular with the Federal Republic of Germany (FRG), Gorbachev's calls for reform invited comparison between the perceived prosperity of capitalism and the previously closed system of Soviet-style economics. When these economic and democratic reforms were exported to the Soviet satellite states, in particular the implementation of Glasnost in late 1986, the retroactively pronounced Sinatra Doctrine in 1989, and the widening political latitudes these policies afforded Eastern Bloc societies, they rapidly unleashed forces that culminated in the democratic turn of 1989, the reunification of Germany in 1990, and, ultimately, the collapse of the Soviet Union (USSR) in 1991.

Since the early 1990s, Gorbachev's reforms, policies, and Deutschlandpolitik (policies relating to Germany) have been judged largely in terms of their effects on Soviet security and economic policies. It is my purpose here to demonstrate how the Materialist and the Realist approaches, those of Soviet economic and security policies in the European arena respectively, are insufficient in themselves to explain Gorbachev's actions and policies throughout the period of the collapse of the Socialist Unity Party (SED) regime in East Germany and German reunification. The Materialist arguments claim that West German economic aid served solely as a payment for the Soviet Union's renunciation of spoils from the Second World War and Gorbachev's sale of the German Democratic Republic (GDR) to the western Federal Republic of Germany (FRG). This view downplays the role and significance of Soviet military power and concerns (Forsberg 2005, 142) and long-standing Cold War divisions. It is, however, important to note how Soviet economic policy and security in Europe and the world fed one another in the formulation of Gorbachev's relationship with the two German states in his ultimate support for a united Germany. That is, German economic incentives and Soviet economic policy and openness to Western economic institutions reduced the need for a sustained military hard-line against the West. At the same time, those economic policies and incentives were only possible once Soviet military concerns were addressed.

\section{The Soviet Role in German Reunification}

Historians such as Randall Newnham ("The Price of German Unity: The Role of Economic Aid in the German-Soviet Negotiations,” 1999) and Mary Elise Sarotte (1989: The Struggle to Create Post-Cold War Europe, 2009) both describe the fall of the GDR in terms of a financial transaction between the FRG and the USSR. In arguing this, Gorbachev is stripped of agency in the events he himself set in motion and is instead portrayed as reacting to circumstances in which he had little or no choice but to comply. There is little to no debate that Perestroika, as initially envisioned by Gorbachev and the CPSU, was meant to be a policy of economic reform. However, both the Materialist and the Realist approaches are concerned with Soviet interests-economics and security, respectively-and treat Gorbachev's role in German reunification and the Soviet withdrawal from empire in terms of these two underlying forces. Alternately, historians such as Tuomas Forsberg, Jefferey Gedmin, and Andrew Bennett propose more theories 
complicated when discussing the Soviet role in German Unification. While the Materialist and the Realist approaches present interesting interpretations of Gorbachev's agency in the last days of the GDR, it is also necessary to integrate them with the concepts of trust and Learning Theory, this latter being referred to by Forsberg alternately as Constructivist and Ideationalist theory, to demonstrate the importance and interrelatedness of the economic and security interests of the Soviet Union.

\section{Agency and Gorbachev: a Theoretical Understanding}

Forsberg describes the core of the Constructivist approach as the achievement of political change through identity change (Forsberg 2005, 145) among one or more of the actors involved. In an analysis of the relationship which developed between Gorbachev and West German Chancellor Helmut Kohl, financial incentives acted as symbols of trust and Gorbachev's belief in Kohl's commitment to future aid and support enabled Gorbachev to meet Soviet economic and security concerns until the collapse of the USSR in 1991. Through this approach to Gorbachev's agency in the events of 1989-90, the Constructivist approach not only points to the Materialist and the Realist as being dependent upon "ideational constructions," but also expands the approach through the incorporation of Learning Theory (Forsberg 2005, 145). This is the process by which Gorbachev's biography serves to explain the new thinking of Soviet leaders since 1985. Apart from biographical accounts that contributed to Gorbachev's thinking and policies, Learning Theory also draws upon previous Soviet policies, both successful and not, and how these earlier efforts affected the lens through which Gorbachev viewed Soviet foreign policy.

\section{Constructivism}

Constructivism as a named theory has appeared in the historiography of the end of the Cold War and the reunification of Germany since, at least, the publication of Forsberg's article "Power, Interests, and Trust: Explaining Gorbachev's Choices at the End of the Cold War" (1999). Though, this is pre-dated by the approach used by Gedmin already in 1992. Regardless, much of the literature on the subject of Gorbachev and his role in German reunification before and since Forsberg's publication, including that which was published in anticipation of the twentieth anniversaries of the opening of the Berlin Wall and the collapse of the communist establishments in the eastern European states in 2009, described and reduced events to their security and economic components arguing that these elements dictated Soviet policy and Gorbachev's sale of the GDR. Thus, the historiography is left with disparate understandings of Gorbachev's rationale as opposed to the integrated and more complex analysis necessitated by Constructivist theory. This paper discusses the three theoretical approaches introduced above and their necessary interaction in order to provide a more thorough analysis of Gorbachev's role in German reunification. It argues that not only was German reunification the unforeseen by-product of Gorbachev's policies of Perestroika and Glasnost, but also that despite the fall of the Berlin Wall on 9 November 1989, the reunification of Germany could not be considered a foregone conclusion until Gorbachev's economic and security concerns for the future of the USSR were met. These concerns were not addressed by traditional measures, but through the trust developed between Gorbachev and the FRG, through Chancellor Kohl. Constructivist theory serves to explain how Gorbachev addressed Soviet concerns and his own policies of reform during the process of German reunification where earlier confrontational policies failed.

As a significant trading partner of the Soviet Union and co-member of the Council for Mutual Economic Assistance (CMEA or COMECON), the CPSU extended Gorbachev's policy of Perestroika to the GDR as it did to all other states in the CMEA. In his address at the $40^{\text {th }}$ anniversary of the GDR on 6 October 1989, Gorbachev stated that "we vitally need perestroika and we firmly believe that it will take our country to further heights and make it possible to bring out the great potential of socialism (Gorbachev 1989a, 13)." With this, Gorbachev did not intend to bring an end to Soviet hegemony or an end to SED authority in the GDR through openness and restructuring, but sought to revitalize socialism through the "free development of all people and their equal participation in the common affairs of the 
country (Gorbachev 1989a, 13)," which included an increase in the standard of living and the assurance of the legitimacy of Soviet-style communist authority in the CMEA states. In promoting this policy, however, Gorbachev did not take into account, either as a failure or as a conscious decision due to his dealings with the FRG and Chancellor Kohl in Bonn, the GDR's need to define itself in direct opposition to the FRG.

Being on the front lines of the Cold War and part of a divided state, the GDR survived in direct competition with the FRG. The SED's own struggle for legitimacy found its source in that competition. The SED, and through the Party the whole of the GDR, defined itself as an anti-fascist and socialist alternative to the FRG (Dennis 2000, 18). Any measure to democratize the political or economic structures of the GDR, as was mandated by Perestroika, served to erode the foundations of the state. Were the GDR to adopt a western market-style economy and reformed democratic political institutions, little argument could then be made against the continued division of two equally peaceful, democratic and capitalist German states as nothing but the inner-German border would serve to differentiate the two. In short, GDR independence was itself dependent upon the SED's hard-line, neo-Stalinist regime. Already the legitimacy of SED rule proved itself almost entirely dependent upon repression and the presence of Soviet occupying forces inside East German borders. On 16-17 June 1953, following an SED reversal of policy and admission of fallibility made at the insistence of the CPSU, a spontaneous worker revolt forced the SED leadership into disarray until Soviet military authorities crushed the uprising (Dennis 2000, 66). In August 1961, in order to curb the rising numbers of East German citizens fleeing to the West via the escape hatch provided by West Berlin, the SED constructed the Berlin Wall (or the "Anti-Fascist Protection Barrier" as it was known by the SED). Although the Wall was built in order to preserve the GDR's existence by stemming the westward flow of East Germany's labour force and intelligentsia, this was not accomplished without the Kremlin's consent (Taylor 2006, 136-7). After Hungary opened the border with Austria in spring 1989 as part of its own experience with Perestroika, the SED restricted travel to their CMEA-partner state (Sarotte 2009, 31), once again closing the valve on East German emigration to the West. Throughout this period (1949-89), however, the SED, with Soviet support, was in complete control of the GDR with only one change in leadership in 1971, which came at the insistence of Leonid Brezhnev (Taylor 2006, 350).

The implementation of Glasnost revealed that the GDR was not as economically sound as believed, with a foreign debt of $\$ 20.6$ billion, a dependency on DM 2.5 billion in annual transfers from the FRG by 1989 and a sliding GNP. The revelation of GDR debt refuted SED claims that all was well with the GDR economy and undermined SED efforts to ignore Perestroika (Jarausch 1994, 101). Unlike the rest of the Soviet bloc, however, by 1989 any East German could readily see the differences in material wealth and living standards between East and West as 85-90 per cent of GDR citizens received West German television stations (Rumberg 1988, 213). With the ease of access to West German media outlets and the perpetual threat to SED control posed by the existence and perceived prosperity of the FRG, potential democratic and economic reform equated to an admission of SED fallibility similar to the one made in 1953. This then threatened the perception of the GDR as a successful, socialist alternative to the West.

\section{The Learning Model}

In "Power, Interests and Trust: Gorbachev and the End of the Cold War" and "Economic Incentives, Ideas, and the End of the Cold War," Forsberg suggests Learning Theory and trust guided Gorbachev's decisions. To these, Andrew Bennett adds that the position Gorbachev took against the use of force against the East German protesters in Leipzig and Berlin precipitated the fall of the Berlin Wall. These concepts do not in themselves explain Soviet-West German relations in the lead-up to German reunification, but serve to fill necessary gaps in logic in both the Materialist and the Realist theoretical approaches. Bennett argues that Gorbachev's need to develop a relationship of trust is best explained in terms of its effect on the aforementioned theories. Just how does the learning model proposed by Forsberg and Bennett serve to explain Gorbachev’s decisions in 1989-90? 
In his own explanation of Perestroika in 1989, Gorbachev supports the notion that, in the confrontation with democracy and the Western systems, Soviet communism ignored "equality of all before the law [and] the rights and freedoms of the individual (Gorbachev 1989b, 18)." Moreover, in his address to the GDR, Gorbachev recognized that, "in the nuclear age...the most acute problems of the times can be solved only through joint efforts (Gorbachev 1989a, 13).” When Gorbachev began his policy of Perestroika, he consciously evoked language about the "common European home." This rhetorical device implied a reorientation on the part of Gorbachev and Soviet foreign policy makers towards an established relationship with Western Europe. In terms of security, as Europe would undoubtedly prove the battleground in the event of the Cold War turning hot, Gorbachev's "common European home” was predicated on the notion of shared responsibility for European security (Forsberg 2005, 157). The relationship developing between Gorbachev and Kohl allowed the Soviet leader to believe that European policy making, especially that between the USSR and the FRG, could facilitate the true international partnership required for this shared responsibility (Forsberg 2005, 158). Evidence of this notion of partnership can most easily be found in the Bonn Joint Declaration of June 1989. While little change was noted on the issue of German unity, improvements were made to economic relations between the states stimulating FRG investments in the Soviet Union and vocational training for Soviet managerial personnel in West Germany (Sodaro 1990, 362).

Even before German reunification became a pressing concern following what has come to be known as the peaceful revolution in Germany and the fall of the Berlin Wall, Chancellor Kohl sought détente with the USSR and the development of a mutual trust with Gorbachev, demonstrating West German support for Soviet reform policy, and facilitating future relations. Beyond the obvious economic successes between the states, both affirmed the right of self-determination "at Bonn's insistence (Sodaro 1990, 361)." Angela Stent interpreted this declaration as having achieved the prime objective of overcoming the division of Europe. And if the division of Europe was overcome, the division of Germany was meant to follow at some point in the future as it was the source of that European division (Stent 1999, 80). Although this may be viewed as Bonn laying the groundwork for German unity should the opportunity arise, as it came to pass in November of that year, Gorbachev's agreement is demonstrative of his potential flexibility on the issue in viewing reunification not as a reward for West German economic assistance but through the long-term process of Soviet-FRG cooperation. That this was part of a larger West German-Soviet relationship, and part of an economic process of signalling closer cooperation finds evidence in Gorbachev's anger at the FRG's decision not to inform the USSR of its moves toward actualizing German unity, in particular Kohl's Ten Point Plan for German Unity of 28 November 1989 (Forsberg 1999, 618).

Further arguments can be made that the process of German reunification was inevitable by the time of the Caucasus Agreement of July 1990, but it is the contention here that this was yet another step in the development of a West German-Soviet partnership along the lines of Gorbachev's new thinking on international policy. Despite the Sinatra Doctrine's approach to the Soviet satellites allowing each the freedom to chart its own course through Perestroika, had East German sovereignty conflicted with Soviet interests, the fall of the SED regime could have been prevented at any time. By not authorizing the use of military force in the suppression of East German popular dissent, Gorbachev chose the relationship built with Chancellor Kohl and the incorporation of the Soviet Union into the international political and economic spheres over the importance of maintaining a socialist regime in the GDR (Shumaker 1995, 100 \& 140). Additionally, Gorbachev removed the concern of a united Germany's membership in the North Atlantic Treaty Organization (NATO) as a potential stumbling block on Germany's road to unity. As most East Germans and a large number of those in the FRG were opposed to full membership of a united Germany in NATO, Gorbachev had the option of forcing Germans to choose between reunification and its Western allies if this conflicted with Soviet security concerns. In not pursuing this avenue, Moscow demonstrated that it experienced a significant re-evaluation of economic interests above those of state security as was, historically, of utmost importance (Forsberg 1999, 611-2). Gorbachev was then reluctant to endanger the newly founded Soviet relationship with the FRG, Western Europe, and the United States. The security ramifications of this policy for the USSR were significant as they no longer considered East 
Germany to be the frontline in a potential East-West conflict and that a united Germany did not pose a threat to future European stability. Rather, German unity would facilitate Soviet incorporation into the established western-European structure. It is important to note that Gorbachev's policy on Germany and NATO gained highly valued West German support for the USSR's entry into the European order and the promise of addressing Soviet security in the Caucasus Agreement of July 1990. This Agreement reduced German military forces, temporarily prevented the extension of NATO structures into the territories of the GDR, and promised that nuclear arsenals would not be stationed in Eastern Europe in exchange for Bonn's economic help and cooperation (Jarausch 1994, 158).

Bennett argues that Soviet force in the suppression of the Eastern European revolutions "would have resulted in unacceptable levels of military casualties, large direct economic costs, and huge indirect economic costs (Bennett 2005, 85).” This article has already developed the idea that military force would create a financial cost for the USSR's ailing economy by endangering the relationships fostered within the "common European home." Though Learning Theory is speculative in nature and limited by an inability to accurately determine what Gorbachev learned and when (Bennett 2005, 102), Bennett stresses that Gorbachev's new thinking was informed by costly Soviet military failures in Afghanistan, Angola, and Cambodia, the growing ineffectiveness of military intervention, and the formative experiences regarding the morality of force (Bennett 2005, 93-4). Forsberg concurs with Bennett's notion, claiming that Gorbachev's “aversion to war tells us why the Soviet Union did not use military power in East Germany" (Forsberg 1999, 610). This aversion to war on the part of Gorbachev is evident in his reorientation of security policy and his unilateral and bilateral agreements to reduce conventional and nuclear forces. However, the developing relationship with the FRG and West Germany's reciprocation of an honest partnership with the Soviet inclusion in European affairs highlighted the failure of the Soviet Union's previous foreign policy of confrontation (Shumaker 1995, 69). While the Constructivist and learning models must be carefully used and do not in themselves provide a single explanation for Gorbachev's new thinking, Constructivism adds a critical dimension to Gorbachev's perception of Soviet military power, its costs, its consequences in relationship-formation with the West, and the arguments made by the Realist theoretical approach. As such, the approaches of Forsberg and Bennett should be kept in mind in any analysis of Soviet security and economic interests as they add important dimensions towards an explanation of Gorbachev's German policy in the late 1980s and early 1990s.

\section{A Realist Approach}

The Realist approach deals largely with Soviet security interests in the relationship between the USSR and the FRG. David Shumaker's study, Gorbachev and the German Question: Soviet-West German Relations, 1985-1990, adopts such an approach. In tracing the significance of Soviet security interests as the core of Soviet-West German rapprochement and how this related to the GDR, Shumaker argues that, by 1989, the GDR was no longer necessary to the security of the Soviet state. Through the development of long-range missiles able to deliver nuclear payloads, the GDR outlived its original purpose as a buffer zone for conventional military forces between East and West. This assurance of Soviet state security without the GDR allowed for Gorbachev's westward turn and the potential for German unity (Shumaker 1995, 102). Throughout his study, however, Shumaker is unable to detach Soviet security from its economic policies. This concept was introduced in the previous section through the analysis of the effects of the politics of trust and relationship building of the "common European home." As Shumaker was unable to discuss security concerns without addressing their impact on Soviet economics and vice versa, he demonstrated that the two concepts were, in fact, intertwined in Gorbachev's approach to German reunification. Rather than attempt to separate the Realist argument from that of the Materialist, Shumaker argues that the redefinition of Soviet security interests allowed its economic interests to take priority through the development of Perestroika (Shumaker 1995, 99).

Through the incorporation of the previously detailed Constructivist Theory, this conception of the

Realist theory demonstrates how the development of trust between the Soviet Union and the FRG, and between Gorbachev and Chancellor Kohl in particular, acted in the interests of meeting the needs of 
Soviet security. The Soviet petitioned, and West German supported, incorporation into the "common European home" was meant to serve Soviet security interests in ways that traditional military force could not. This policy reduced the obvious need for a large military and, coupled with the nuclear deterrent, shrank the borders in need of military defence. Simultaneously, the "common European home" reduced the need for that nuclear deterrent by allying the two opposing ideological forces of the Cold War. The application of Forsberg's Learning Theory model is then able to explain how the rising costs of nuclear and conventional military parity and military setbacks in Afghanistan, Angola, and Cambodia affected Gorbachev's approach to nuclear proliferation. The failure of a costly aggressive posture in Soviet security policy allowed Gorbachev the opportunity to achieve the desired ends of state security through economic negotiation and bi-lateral and multi-lateral cooperation.

By the late 1980s, the Soviet Union was spending an enormous percentage of its annual GNP on its immense conventional weapons arsenal and on maintaining nuclear parity with the United States. At the same time, however, Gorbachev did not fear war coming from the West and considered the Soviet state secure due to its nuclear arsenal (Forsberg 1999, 613). This did not make the Eastern European states expendable as suggested by Shumaker, but greatly reduced their overall importance in Soviet strategic thinking as they no longer provided the buffer zone they once did due to U.S. missiles stationed throughout Europe, more generally, and the FRG, in particular. Moreover, the ailing Soviet economy could no longer afford to maintain the arms race (Forsberg 1999, 608). As previous Soviet strategy seeking to meet the West with force proved ineffective, Gorbachev sought a more productive diplomatic relationship with the West and Bonn (Shumaker 1995, 4). To facilitate cooperation with Bonn, in December 1988 the Soviet Union unilaterally announced a reduction in its overall conventional forces stationed throughout Europe (Shumaker 1995, 72). Although potentially counter-productive to Soviet security, nuclear parity and mutually assured destruction maintained the security of the state. Reducing Soviet conventional forces was a direct response to a decision made the previous year by Chancellor Kohl not to modernize the Pershing 1A missiles stationed in the FRG. As any new war would start on German soil, the meeting point between the communist East and the democratic West, this was an important step in fostering trust between the Gorbachev and Kohl (Shumaker 1995, 72). With his response, Gorbachev signalled to the Western world, especially to those hawks attempting to justify the continuation of the arms race through a comparison to Soviet capabilities, that Soviet foreign policy was no longer dictated by confrontation with the West (Shumaker 1995, 83).

From these actions, it is possible to understand how the re-conceptualisation of Soviet security informed Gorbachev's understanding of relations between the USSR and the FRG. Considering SovietUS nuclear parity and the improbability of war through mutually assured destruction as being sufficient to meet Soviet security interests, Gorbachev turned his attention to fostering relations with Kohl and the Federal Republic through the reduction of conventional arms and the incentive of reopening the German question. Already in 1987, Valentin Falin said that the 1971 Quadripartite Agreement was "not the last word on Berlin (Sodaro 1990, 353)." This did not imply that German reunification would happen soon, if at all, but was intended as an olive branch to the FRG.

However, it is impossible to claim that security issues were the only forces guiding Gorbachev in the late 1980s. Shumaker's study necessarily explains Soviet security and the reorientation of security interests as having informed economic interests which allowed those economic interests to take precedence. This being the case, I do not treat the economic signals from Moscow as being separate from its security concerns, but rather wish to demonstrate how these processes were connected in the process of German reunification.

Drawing on Constructivist thought and Learning Theory, the failure of previous Soviet foreign policy allowed for this re-evaluation of the Soviet approach to security and economic concerns and found both to be adequately met through the development of Soviet relations with the Bonn government.

As briefly described above, Gorbachev's policy of Perestroika began life as an economic policy designed to improve the quality of life for the Soviet population and bring an increase to the USSR's lagging GNP. In the opening paragraphs of Gorbachev's address on "The Socialist Idea and Revolutionary Perestroika,” already five years into the reforms, he states that: 
As perestroika reaches the "dense layers" of economic and public life...we have come to the realisation that a radical overhaul of the entire social edifice, from its economic foundation to the superstructure, is essential (Gorbachev 1989b, 5).

\section{A Materialist Approach}

While this involved a deliberate withdrawal from the Soviet empire in terms of directing and financing fraternal regimes, those states of the CMEA, there was no intent to abandon socialism within the Soviet Union or within the satellite states (Gedmin 1992, 2). The Materialist approach claims that economics and the search for Western funding to promote Gorbachev's restructuring of Soviet economic institutions were the most fundamental forces behind Gorbachev's withdrawal from empire and Soviet acceptance of German reunification. While not wholly a subscriber to this theory himself, Forsberg breaks down the Materialist into three distinct categories: as "a face-saver, a payment, or a signal (Forsberg 2005, 147)."

Forsberg understands economic transfers as face-savers in that they "are important in facilitating agreement under coercion (Forsberg 2005, 148)." That is to say that when one side in this relationship is forced to relinquish something to an adversary, in this case the USSR being forced to give up the GDR to the FRG, financial payments allow the first party to retain its honour at the same time as it allows future relations between the two parties to proceed without "unnecessary embitterment (Forsberg 2005, 148)." In this case, the Soviet Union was not forced to concede the GDR. The FRG lacked the military force necessary to coerce Gorbachev to give up East Germany. If anything, Moscow's perceived control over the socialist GDR placed the Soviet Union in a position of strength over its negotiating partners in Bonn. However, as Bonn was not forced, but willing to concede financial transfers to the USSR, the relationship being developed between the two states does not fit this conception of economic transfers as face-savers.

The Materialist idea of economic relations between the FRG and the Soviet Union as a payment are the basis of the theory alternately referred to as Kohl's buy-back or Gorbachev's sale of the GDR. While it is widely known that the Soviet Union's economy was in a state of significant stagnation while the costs of the Cold War with the United States and Western Europe mounted, reaching 19-25 per cent of the Soviet Union's total 1.4 trillion GNP, the idea of payment, like face-saving, fails to account for FRGUSSR relations beyond the immediate context of German reunification (Gedmin 1992, 8). Payments are typically treated as one time affairs. As arrangements between Bonn and Moscow were intended to work towards long-term cooperation and the social and economic introduction of the USSR into a "common European home," as opposed to a single financial transaction, the idea of economic relations as payment for Gorbachev's sale of the GDR equally does not fit this Soviet-West German relationship.

In considering the Materialist idea of economic transfers as a signal and how they play into Gorbachev's involvement in the reunification of Germany, it is important to understand the turn taken by Soviet foreign policy in 1985 when the policy of Perestroika came into effect. In developing a foreign policy in line with Perestroika, Gorbachev made an integral link between the Soviet economy and international relations (Gedmin 1992, 8). In doing so, Gorbachev understood economic progress and scientific and technological advancements, which the USSR was sorely lacking, to be essential ingredients for national security. This understanding, in turn, established a connection in Gorbachev's new thinking between the Materialist and the Realist approaches. Security was then linked to the international sphere in that "the security of one state could not be achieved at the expense of others (Sodaro 1990, 325).” This security entailed a significant détente between the USSR and the West and a distancing of the USSR from the economic burdens of the CMEA states. In addition, the USSR applied to both the International Monetary Fund (IMF) and the General Agreement on Tariffs and Trade (GATT) as part of the Soviet Union's move to incorporate its economy into the global economy (Gedmin 1992, 8).

However, with the Soviet economy still lagging, in 1989 Gorbachev stated that "socialism has proved itself incapable of becoming the leader of structural perestroika" and that the necessary economic reforms needed cash (Gorbachev 1989b, 25). Mary Elise Sarotte indicates that by this time the FRG was the only Western state left that would still consider investment in the USSR (Sarotte 2009, 151). As the FRG, led by Helmut Kohl, demonstrated its willingness to support Soviet reforms, West Germany 
extended the prospect of long-term economic partnership that proved "more important than their direct economic utility (Forsberg 2005, 146).” Regardless of Kohl's intentions at the time, this should not be interpreted as part of the supposed buy-back of East Germany. This partnership predates the political upheavals of 1989 in the GDR by two years and commits the FRG to long-term investment in the USSR rather than a one-time payment (Newnham 1999, 425) necessitated by either the concepts of economic transfers as face-saver or of payment toward the purchase of the GDR.

In her own study of German unification, Sarotte identifies West German payments to the Soviet Union, a DM five billion credit on 13 May 1990 followed by DM 12 billion and an additional interestfree DM three billion credit on 10 September of the same year among other incentives (Sarotte 2009, 160), as an effort on Helmut Kohl's behalf to bribe the USSR out of its World War II claims to the GDR and acquire Gorbachev's consent for reunification (Sarotte 2009, 192-3). For Gorbachev's part, these West German gifts allowed him to save face among other members of the CPSU and the Politburo as a demonstration that the loss of the GDR, and subsequently the nullification of gains from the Soviet victory in the Second World War, served a significant end (Sarotte 2009, 151). One can assume that Chancellor Kohl and all chancellors since Willy Brandt and his policy of Ostpolitik (the FRG's East German policy), considered reunification to be a potential component of any and all dealings with the Soviet Union. However, Sarotte's study covers only the period from summer 1989 until German reunification in October 1990. Given such a narrow window of focus, one may come to view FRG-Soviet relations as a financial transaction towards the goal of German unity. Sarotte's approach, however, fails to consider important details of West German-Soviet relations throughout the Gorbachev era.

In his own interpretation of Materialist Theory as a form of payment between states, here the USSR and the FRG, Forsberg contends that two problems were inherent in such an exchange. First, there is an extreme level of difficulty in determining a dollar value for the GDR or any other state, for that matter. Second, and perhaps more important, adversaries, such as the USSR and the member-states of the NATO, are less likely to engage in this type of exchange on issues closely tied to national security (Forsberg 2005, 149-50). While this latter concept treads dangerously close to the Realist theory discussed above, part of it is necessary for discussion here. Throughout the Cold War, the division of Germany was considered necessary for the continuation of European peace. Apart from the notion of a divided Germany serving as a buffer and potential frontline between East and West, the membership of a united Germany in NATO proved an unacceptable shift in world power and security (Jarausch 1994, 163). In his address at the $40^{\text {th }}$ anniversary of the GDR, Gorbachev touched on this idea, stating that "we do not idealize [the situation in Europe]. The heart of the matter is...that to this day it is a recognition of the post-war realities which has ensured peace (Gorbachev 1989a, 10).” As noted by Forsberg, in 1988 Gorbachev received an offer of DM 500 billion from German industrial circles for his consent to German reunification (Forsberg 2005, 154). Had Gorbachev been inclined to sell the GDR, as implied by Sarotte and Newnham elsewhere in this paper, the offer of DM 500 billion would more than settle accounts between the Soviet Union and the FRG and was well in excess of the actual credits extended to the USSR by the Kohl government in 1989-90. This offer did nothing to satisfy Soviet security concerns and was rejected as "it simply did not seem serious at the time (Forsberg 2005, 154)." Although payments to the Soviet Union from the FRG were ultimately substantial, Randall Newnham estimates this figure to be around DM 87.5 billion through direct and indirect aid, money was unable to purchase the security required by the Soviets or maintain the status quo of post-war Europe (Newnham 1999, 437).

Additionally, Forsberg contrasts the issue of German reunification to Japanese attempts to buy the independence of four Kurile Islands in 1991. In this case, economic efforts at a payment solution failed to do anything beyond strengthen Moscow's resolve against them, as there was no relationship of trust built between the two states (Forsberg 2005, 161).

The problem with Sarotte's interpretation of German reunification solely as an economic transaction is that it implies that the USSR was coerced into relinquishing its rights to the GDR by forces beyond those of economics. The FRG lacked the military capacity or will to force the Soviet Union from GDR territory. As the USSR had a standing army of approximately 400,000 inside East German borders, in addition to residual occupation rights from the Second World War, this always allowed the Soviet 
Union the final say regarding German reunification (Sarotte 2009, 9). Although it is true that, following the opening of the Berlin Wall on 9 November 1989, the drive toward unity was immense and Soviet options grew more limited as events progressed, not once did Gorbachev, the CPSU, or the Soviet military attempt to stop or even slow those events (Bennett 2005, 97; Gorbachev 1989a, 7). This followed the whimsically named Sinatra Doctrine, allowing East European states to chart their own course through Perestroika and to do so their way. As such, the lack of coercive forces in the events leading to German reunification, beyond the perceived will of the German people themselves, contradict Sarotte's notion of Gorbachev's sale of the GDR and that of economics playing the role of a face-saver.

\section{Conclusions}

It is therefore necessary to understand how economic policy between the FRG and Moscow acted as signals from one government to the other as emblems of each regime's genuine intentions. In doing so, Materialist and Constructivist thought are connected as money was a tangible signal of the development of cooperation and trust between Gorbachev and Kohl. Through Perestroika, Gorbachev sought to restructure Soviet economic institutions through their incorporation into the global markets. Regardless of Kohl's possible intention to foster the notion of German unity at some time in the future, as embedded in the Preamble to the FRG Basic Law, Kohl was responsive to Soviet manoeuvres and gave Gorbachev faith that the USSR was on the correct course and would be welcomed into the European system in its efforts to reform (Forsberg 2005, 157). Such long term relationships, and relationships that extend beyond the realm of pure economic relations, cannot therefore be solely explained by the Materialist notions of either face-saving or payments transactions. The process of German reunification only became inevitable after Gorbachev laid the groundwork to facilitate the Soviet Union's entrance into the "common European home." He was not coerced into allowing the collapse of SED control nor was he a bystander as the GDR was enveloped by the economic might of the FRG, as argued by Mary Elise Sarotte and Randall Newnham. Rather, Gorbachev enabled German unity through his reorientation of Soviet policy and his reluctance to use military force. By the time the Berlin Wall fell on 9 November 1989, Gorbachev already allowed the formation of a pluralist political structure and the election of a non-socialist government in Poland and the opening of the Hungarian border with Austria. While hopes of a reform minded socialist government coming to power in the GDR was not to come to pass, Gorbachev fully supported the selfdetermination of the East European states (Beissinger 2009, 335). Gorbachev's Foreign Affairs Minister Eduard Shevardnadze said that "the Wall would fall when the conditions were right, but that this required a certain degree of trust and respect among all sides (Stent 1999, 80).” Through Gorbachev's relations with the FRG, these conditions, the trust, and the respect spoken of by Shevardnadze were met without the aggression displayed by previous generations.

This paper has demonstrated that no single theory is sufficient to explain Gorbachev's decisions at the end of the Cold War. Instead, it was the goal of this paper to emphasize the interplay and interrelatedness of these theories and, more importantly, to show how Soviet economic and security policies each informed Gorbachev's approach to the other and to his dealings with Helmut Kohl and the FRG. The extension of Kohl's economic incentives toward Gorbachev's Soviet Union remains at the heart of the Materialist argument. The Constructionist view allows us to interpret these manoeuvres not as face-savers or as payments, which make the assumption that German reunification was inevitable by early 1990 as suggested by Sarotte and Newnham, but as signals towards the formation of a deeper West German-USSR relationship through Kohl's support of Gorbachev's notion of the "common European home.” Likewise, Realist thought considers that Soviet security was met by nuclear-parity. This allowed the re-conceptualisation of the Eastern European states, the GDR most importantly, in terms of their strategic importance and turned Gorbachev's thoughts towards economic concerns. However, Constructivism adds a significant dimension to this by way of Gorbachev's apparent aversion to war and previous military failures. Gorbachev's reduction of Soviet conventional forces in Eastern Europe was just as much a signal as were Kohl's economics. Gorbachev sacrificed Soviet security to demonstrate his commitment to West Germany and East-West integration, thereby further securing the USSR in both 
economic and military terms. In this way, Constructivism informs our view of both the Materialist and the Realist approaches. At the same time, economic and security interests operated simultaneously in Gorbachev's new thinking and in the relationship between Gorbachev and Kohl, both working toward the goal of securing the future of the USSR.

\section{REFERENCES}

\section{SECONDARY SOURCES}

Beissinger, M.R. 2009. “Nationalism and the Collapse of Soviet Communism.” Contemporary European History 18 (3): 331-347.

Bennett, A. 2005. “The Guns that Didn’t Smoke: Ideas and the Soviet Non-Use of Force in 1989.” Journal of Cold War Studies 7 (2): 81-109.

Dennis, M. 2000. The Rise and Fall of the German Democratic Republic, 1945-1990. Harlow: Pearson Education Limited.

Forsberg, T. 2005. "Economic Incentives, Ideas, and the End of the Cold War: Gorbachev and German Unification.” Journal of Cold War Studies 7 (2): 142-164.

---. 1999. "Power, Interests and Trust: Explaining Gorbachev’s Choices at the End of the Cold War.” Review of International Studies 25: 603-621.

Gedmin, J. 1992. The Hidden Hand: Gorbachev and the Collapse of East Germany. Washington: AEI.

Jarausch, K.H. 1994. The Rush to German Unity, New York: Oxford University Press.

Mandel, E. 1989. Beyond Perestroika: The Future of Gorbachev's USSR, London: Verso.

Newnham, R. 1999. "The Price of German Unity: The Role of Economic Aid in the German-Soviet Negotiations.” German Studies Review 22 (3): 421-446.

Oldenburg, F.S. 1989. “Correlations between Soviet and GDR Reforms.” Studies in Comparative Communism 22 (1): 77-91.

Pons, S. 2009. “Western Communists, Mikhail Gorbachev and the 1989 Revolutions.” Contemporary European History 18 (3): 349-362.

Rumberg, D.W.W. 1988. "Glasnost in the GDR? The Impact of Gorbachev's Reform Policy on the German Democratic Republic.” International Relations 9: 197-227.

Sarotte, M.E. 2009. 1989: The Struggle to Create Post-Cold War Europe. Princeton: Princeton University Press.

Shumaker, D.H. 1995. Gorbachev and the German Question: Soviet-West German Relations, 1985-1990. Westport: Praeger.

Sodaro, M.J. 1990. Moscow, Germany, and the West: from Khrushchev to Gorbachev, Ithaca: Cornell University Press.

Stent, A.E. 1999. Russia and Germany Reborn: Unification, the Soviet Collapse, and the New Europe. Princeton: Princeton University Press.

Taylor, F. 2006. The Berlin Wall: A World Divided, 1961-1989. New York: Harper.

Tismaneanu, V. 2009. “The Revolutions of 1989: Causes, Meanings, Consequences.” Contemporary European History 18 (3): 271-288.

Willnat, L. 1991. "The East German Press during the Political Transformation of East Germany.” International Communication Gazette 48: 193-208.

\section{PRIMARY SOURCES}

Gorbachev, M. 1989. Address by Mikhail Gorbachev at the Meeting to Mark the $40^{\text {th }}$ Anniversary of the German Democratic Republic. Berlin, October 6, 1989, Moscow: Novosti Press Agency.

---. The Socialist Idea and Revolutionary Perestroika. Moscow: Novosti Press Agency. 
---. To Build Up the Intellectual Potential of Perestroika. Moscow: Novosti Press Agency.

Plenary Meeting of the CPSU Central Committee. Moscow, Kremlin, September 19-20, 1989, Moscow: Novosti Press Agency. 